$$
\text { "tmcs-turcsanyi" — 2012/11/26 - 12:05 — page 309 — \#1 }
$$

\title{
Virtual Worlds in Education - best practice, design and research considerations
}

\author{
Márta Turcsányi-Szabó, Ladislav Csízi and LadislaV VÉGH
}

Abstract. The article briefly describes and characterizes the virtual worlds, different kinds of virtual worlds and possibilities of their use in education. The virtual worlds beyond the passive learning opportunities offer active, constructive and collaborative learning possibilities as well. In the middle section of this article we present the most common ways of different kinds of learning methods, which are illustrated by practical examples as well. In the final sections of the article we deal with the design research approach of 3D virtual worlds.

Key words and phrases: virtual worlds, best practices, design research, educational use. ZDM Subject Classification: U05.

\section{Introduction}

As different types of Multi-User Virtual Environments (MUVE) emerged we read a lot about attempts of their use in education. These modern environments offer many different kinds of learning possibilities. Especially in the last few years, after the release of $3 \mathrm{D}$ virtual worlds, we experienced significant increase of their use in education.

Users in modern, 3D, multi-user virtual environments are represented by self-designed avatars. Using these avatars they can move in the virtual world,

The European Union and the European Social Fund have provided financial support to the project under the grant agreement no. TÁMOP 4.2.1./B-09/KMR-2010-0003.

Copyright (C) 2012 by University of Debrecen 


$$
\text { "tmcs-turcsanyi" — 2012/11/26 - 12:05 — page 310 — \#2 }
$$

communicate and collaborate with others, express their feelings, give advice to each other, create, modify or buy different objects in the virtual environment. In some virtual worlds virtual land could be bought or leased for virtual money. For example, in Second Life one can buy things or rent a virtual land for Linden dollars (L\$), which is sold for real money and the exchange rate changes daily. Many virtual worlds have built-in programming language as well, e.g. in the Second Life it is the Linden Scripting Language. Using the built-in languages the users have opportunities to react to the different events of objects. They can influence the behavior of the avatars as well, for example they can teach their avatar to swim or dance. One of the great advantages of the virtual worlds is that they are not attached to any location. Users can connect to the virtual world and join activities in this environment from any geographical position of the world. Due to this feature, virtual worlds are usable for distance learning as well.

There are several different types of virtual worlds on the internet. Parts of these are game-based virtual worlds, also called massively multiplayer online roleplaying games (MMORPGs). In this game-based world some rules are laid down and the virtual world contains pre-defined goals to achieve better results or win the game. Game-based virtual worlds are for example EverQuest (www. everquest. com) or World of Warcraft (www.worldofwarcraft.com). Another large group of virtual worlds are open culture virtual worlds. This type of virtual environment doesn't contain any pre-defined rules or goals [12]. Such virtual worlds are Second Life (www.secondlife.com), Active Worlds (www.activeworlds.com), IMVU (www. imvu.com) and Kaneva (www.kaneva.com). Especially the last group of virtual worlds can be used effectively in education. In the remaining parts of this article we will focus on the most commonly used open culture virtual world, Second Life [10], and the possibilities of its use in education.

\section{Education in Second Life}

Modern educational facilities and the potential of using virtual worlds in teaching and learning were recognized by many educational institutions. Second Life is used by approximately 300-400 universities in the world for education and research purposes [9], [14], [21]. Virtual replica of several world-renowned universities can be found in this $3 \mathrm{D}$ virtual environments, including the Oakland University (http://slurl.com/secondlife/Oakland\%20University/128/128/27), the Ohio University (http://slurl.com/secondlife/ohio\%20university/20/ 36/24), the Hong Kong Polytechnic University (http://slurl . com/secondlife/ 


$$
\text { "tmcs-turcsanyi" — 2012/11/26 - 12:05 — page 311 — \#3 }
$$

HKPolyU\%20Campus/185/183/25) and the University of Edinburgh (http:// slurl.com/secondlife/Vue/205/53/30). The Faculty of Law at Harvard University starts online courses within the virtual world with the possibility of obtaining real credits. On these courses students participate from China, South Korea and other countries around the world. There is a possibility for further trainings of the university staff as well as obtaining new sponsors at the virtual campus of the Harvard University [12].

Perhaps the most common and most widespread use of Second Life in education is organizing conferences and seminars in the classrooms of the virtual university campuses. Virtual worlds, however, beyond this kind of passive information acquisition provide many modern, student-centered, active, constructive and collaborative learning opportunities [9]. We will introduce some of them in the next sections of this article.

\section{Main learning methodologies in virtual worlds}

Several learning methodologies are used in virtual worlds and they can be classified as follows [11], [21]:

- Learning by observation and discovery - learning occurs by observing different objects, communities, landscapes, or by discovering the virtual world itself and the virtual environment [11], [20], [21]. For example, visiting virtual museum exhibitions, interesting architectures, observing frescoes of the Sistine Chapel (http://slurl .com/secondlife/Vassar/166/88/25) in Second Life.

- Learning by cooperation and joint problem solving - learning through cooperation and collaboration, where the aim is to implement a common project in virtual world and to find solutions to different problems [9], [11], [20].

- Learning by existence and imitation - students learn by discovering themselves and their identities in virtual worlds [11], observe and imitate positive behavior forms in virtual worlds [21]. This category contains for example role-playing games to practice foreign languages, games to solve different situations in virtual worlds [9].

- Learning by constructing and creating - learning by creating new objects in virtual worlds and writing associated program codes using Second Life's Linden Scripting Language [11]. This kind of learning may be useful especially during learning certain topics of mathematics and computer science. For 


$$
\text { "tmcs-turcsanyi" — 2012/11/26 - 12:05 — page 312 — \#4 }
$$

example CS students can create a robot in Second Life which will always follow his owner [6]; hotel industry students may design and furnish a hotel's guest room [15].

- Learning by patronizing - learning comes from initiating solutions to realworld adoption, patronization and missionary problems by different virtual worlds' communities. E.g. organizing meetings in virtual world and realizing social life for disabled people; creating exhibitions in virtual world with the aim of raising awareness of real-life problems [11].

- Learning by narration of virtual world events - creating, modifying and editing websites, podcasts, blogs, videos which describe virtual world events and activities [11]. Although this type of learning doesn't take place directly in the virtual worlds, it's closely interrelated with them. Students learn the video and audio editing techniques; acquire rules of creative writing, criticism, etc.

\section{Possible problems of using virtual worlds in education}

Despite the fact that virtual worlds are often used effectively in education, in some cases there may be problems which can go to the expense of effective learning. Such difficulties may include, for example if students do not accept Second Life as an educational tool, they do not master the proper use of this world before searching the solution for a complicated problem, or technical problems arise during the learning in virtual worlds. In addition, there is the possibility of diversion of attention by other avatars, which are not included in the study group. Misinformation due to the environment and pornography can be also a problem [9]. In the classroom based education in many cases a problem can also be securing the high hardware and fast internet requirements of Second Life.

\section{Some example projects on how to use virtual worlds in education}

Virtual worlds used in education, such as Second Life, are not toys. There are no goals which can take us to the next game levels. Second Life is just a 3D virtual environment, which is available on the Internet, and in which different individuals and groups can come together to collaborate [9]. In order for students to acquire new active, constructive and collaborative knowledge in this environment, first of all a good project or a task is required which can be accomplished by the students 
in the virtual world environment. Finding such a project is not an easy task for the teacher, since (s)he must consider, and often has to try the feasibility in the virtual environment. However, in most cases, the teacher's efforts pay off, because by working on the project students gain new knowledge while playing, constructing and learning collaboratively. Further in the article we would like to point out some of these projects, focusing especially on teaching of foreign language, photography, commerce, programming, tourism, hospitality and computer animation.

One of the methods of teaching and practicing language within Second Life is, when students meet in various locations in the virtual world (e.g. restaurants, shops, museums, exhibitions, theaters, bus stops or train stations) where they can talk to each other and to the teacher in various situations using the microphone [18]. This kind of conversation has several advantages against classical education in classroom. One of these benefits is that students in general are more courageous and without any stage fright joining the discussions, as they often do not know each other personally and can see each other only through a $3 \mathrm{D}$ virtual-world avatar. Another major advantage of teaching and practicing language within Second Life is when native speaker students join the group from different parts of the World. The virtual environment allows not only the practicing of a language within a language course. Students may attend different virtual world events where the conversation happens in a given language. [12].

Second Life can also be used in teaching photography. Within the frameworks of a project, students of the University of Leicester (http://slurl.com/ secondlife/Media\%20Zoo/170/150/17) had the task to observe different groups of people in the virtual world, find interesting places, buildings and take pictures - snapshots of these. Participants were then asked to place the best and most interesting photos on the sides of a cube (storycubes) and thus create a virtual exhibition (Figure 1). Finally, the students created different stories by putting the cubes next to each other and rotating them [17].

Virtual worlds are also excellent for teaching entrepreneurship. Within the framework of a project [16], students were assigned to create a bulletin board in the virtual environment. They had to write the name of their company and their ideas on the board. Later they designed and created their company's logo together and they put it above the entrance of the virtual shop. In their virtual store students exposed photos of products they made in school, e.g. on art lessons, drawing lessons (wallet, pen, bookmark, etc), which they were selling in reality $[16]$. 

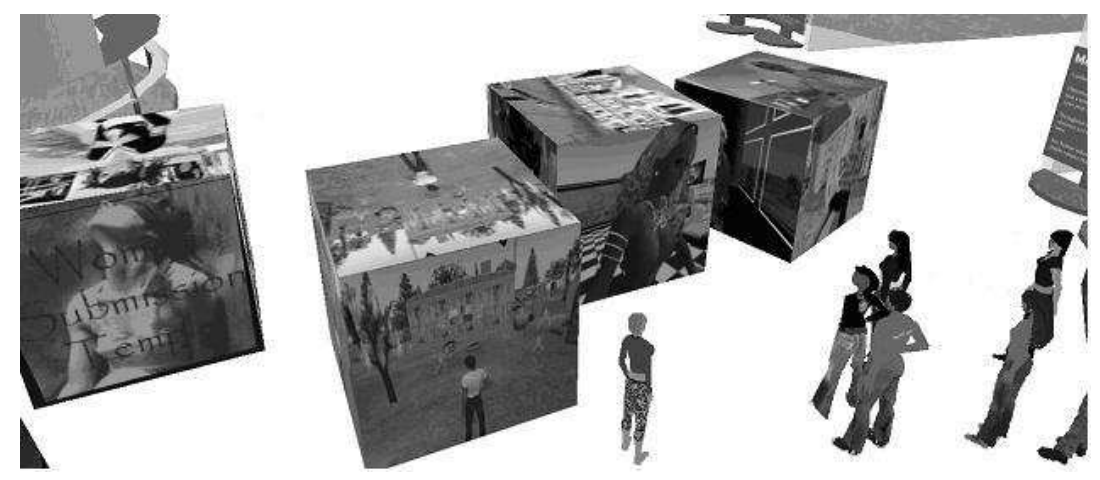

Figure 1. Photo exhibition on the virtual cubes [17]

During teaching programming in Second Life [6] students' first task was to create various 3D objects (e.g. dog, robot, car) and write the necessary code for objects' behavior (e.g. the dog is following its owner) using the built-in Linden Scripting programming language. Students can work together on the same object and write the corresponding code in the virtual environment (Figure 2). The teacher has the option to view the upcoming program code anytime and he can comment on them if necessary [6].

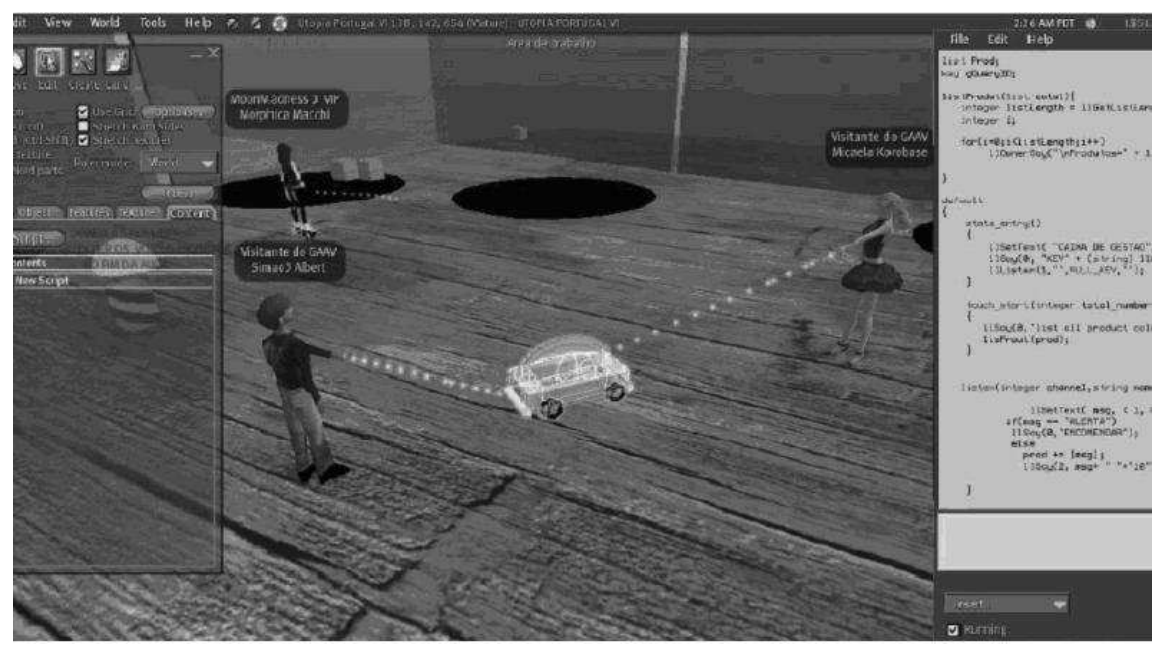

Figure 2. Within the programming course two students created the same object together [6] 


$$
\text { "tmcs-turcsanyi" — 2012/11/26 - 12:05 — page 315 — \#7 }
$$

During catering and tourism education, students had the task to design and furnish the guest rooms of a virtual hotel in groups and then jointly evaluate the implementations [15]. During teaching these subjects - but within the frameworks of another project - students took part in a role-playing game. One group of students played guests while another group played the hotel's employees. In the role-playing game the hotel's staff tried to find a solution for various problems arising among the guests [15].

Successful attempts were also made in the use of Second Life in teaching computer animation and graphics [7]. The course includes virtual-world lectures, solutions of practical exercises and a final exam. During the week-long seminars the lecturer presented algorithms used for animations by $3 \mathrm{D}$ virtual world objects. The formulation of practical exercises in the virtual world was motivated by the wizard school in Harry Potter novels. The students were using text chat, and they had to instruct certain objects for movement and transformation by saying "magic words". They used the Linden Scripting programming language built into Second Life for writing the scripts solving the pre-prepared sample cases. During the final exam they presented their theoretical work to each other using virtual world posters. Then they had the chance to try the practical implementations of the projects which were animations created using virtual world $3 \mathrm{D}$ objects or using the OpenGL projected on the virtual world [7].

There are lots of other projects not mentioned here which were created for teaching of other subjects (http://www.nmc.org/pdf/NMC-Virtual-WorldsSurvey-Listing.pdf). They take advantage of knowledge-learning possibilities given by $3 \mathrm{D}$ virtual worlds' modern environment.

\section{Designing 3D virtual worlds - when is it worth the effort}

At the planning stage, one has to answer several questions in order to determine how much effort is necessary to put into the design process to come up with an efficient solution worth the effort?

It is well worth to look into the investigation of design effort to stage the particular collaboration vs. 3D added value affecting the quality of learning outcomes based on the classification of collaboration and learning pattern [20].

The figure illustrates well the diversity of efficiency in learning outcomes for designing different types of collaborations through the mapping of patterns [20]: 


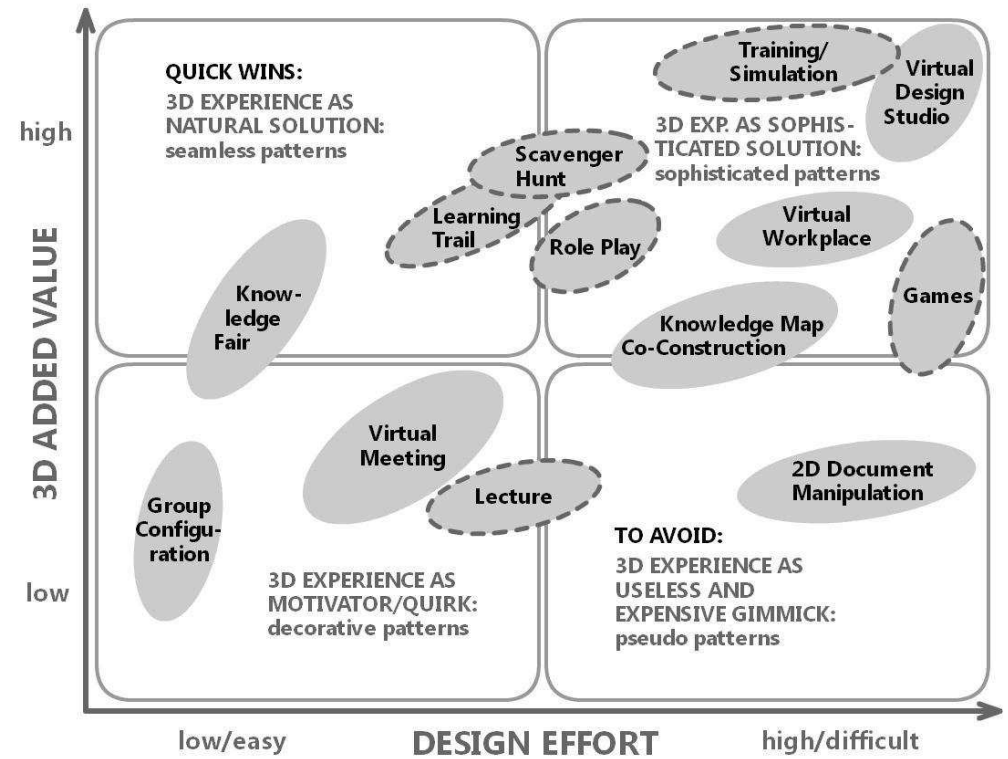

Figure 3. A classification of collaboration patterns (ellipses with straight outlined) and learning patterns (ellipses with dotted outline) by design effort and 3D added value [20]

- at the lower left end: meetings and lectures are easy to design and 3D would only provide decoration;

- at the lower right end: excess of 3D efforts are declared useless, as a more simple solution like the use of Google Docs might prove to be more efficient;

- at the higher left end: events like Knowledge fairs where simple elements (posters and video/slides) are presented are considered to quick wins, as the $3 \mathrm{D}$ added value requires only low design efforts;

- at the higher right end: training/simulation, as the most sophisticated solution contain the most $3 \mathrm{D}$ and interaction patterns, depending on the necessity of reality features.

\section{Which 3D world should we choose as platform}

Second Life was designed to support a virtual economy and to generate revenue for Linden Labs, using inworld currency (the Linden dollar or L $\$$, that can 


$$
\text { "tmcs-turcsanyi" — 2012/11/26 — 12:05 — page 317 — \#9 }
$$

be bought and sold for US dollars). Thus buying land, 3D objects and a lot of key actions within Second Life requires us to pay a lot of $\mathrm{L} \$$. Thus the choice of platform does not only depend on methodological considerations, but also bears severe budgetary issues that have to be measured on the other side of the pane.

The Association of Virtual Worlds put together the Blue Book [2] containing over 300 existing and upcoming worlds for entertainment, education, healing and socializing that are categorized, tagged and linked for trail and experience. A careful consideration and comparison of features and design efforts vs. aimed outcomes is needed to provide tools for suitable configurations and ongoing developments for a sustainable longitudinal study to take place.

\section{The Design Research Approach}

Considering the importance of the learning environment, one can find advanced literature about the design of web-based systems, including also a number of useful design principles. However, virtual world research has emerged only recently and does not yet have theoretical development principles that directly inform and guide design.

The Design Science Research (DSR) Approach is a problem-solving process used to develop an IT articraft in the form of constructs, models, methods, instantiations, or better theories and through the process itself enables a better understanding of the development, implementation, and use of the information systems itself [22].

Guidelines for taking appropriate steps in development have been compiled based on research.

But, it is not only the system perspective, but also the cognitive perspective that need to be taken into consideration, which needs a research paradigm, that analyses the individual's cognitive processes as well as its social context in order to understand how cognition and learning takes place within the virtual world.

Design-based research assumes that context affects learning, offering a methodological tool kit to systematically and iteratively test and improve a designed learning environment and to generate theory alongside [4]. Considering the characteristics and affordances of virtual worlds, an adaptation was proposed to be used for virtual world research projects [19], which is very much in favor of the authors of this paper too. The guidelines describe the following steps to be taken: 


$$
\text { "tmcs-turcsanyi" — 2012/11/26 - 12:05 — page 318 — \#10 }
$$

Table 1. Mapping of seven DSR guidelines onto the five steps process [8]

\begin{tabular}{|l|ll|}
\hline \multicolumn{1}{|c|}{ STEP } & \multicolumn{1}{c|}{ GUIDELINE } \\
\hline 1. Problem awareness & $\begin{array}{l}\text { 1. } \\
\text { 2. }\end{array}$ & $\begin{array}{l}\text { A new and innovative artifact needs to be developed. } \\
\text { The artifact needs to be a response to a clear and } \\
\text { relevant business problem that is identified by the re- } \\
\text { searchers }\end{array}$ \\
\hline 2. Suggested design & $3 . \begin{array}{l}\text { Proper evaluation measures and methods regarding } \\
\text { the utility, quality and efficacy of a design artifact } \\
\text { need to be defined. } \\
\text { The research outcome needs to have a clear research } \\
\text { contribution and not only be limited to usefulness for } \\
\text { practitioners. }\end{array}$ \\
\hline 3. Development & $\begin{array}{l}\text { 5. } \\
\text { Proper research methods need to be applied in devel- } \\
\text { oping the artifact. } \\
\text { Several iterations are needed to tweak the artifact to } \\
\text { the initial requirements. }\end{array}$ \\
\hline E. Conclusion & 3. $\begin{array}{l}\text { The artifact needs to be evaluated using the evalua- } \\
\text { tion measures and methods previously defined. }\end{array}$ \\
\hline & 7. & $\begin{array}{l}\text { Results need to be communicated to practitioners and } \\
\text { researchers. }\end{array}$ \\
\hline
\end{tabular}

Step 1) Describe the virtual word in term of:

- Theory that supports the virtual world.

- Teaching and learning principles used to design the virtual world.

- Settings where the virtual world would be used.

- Relevant learners' characteristics.

- Stated learning objectives.

- World's contextual characteristics.

- Learning activities that users are expected to perform inside the learning environment.

- Goals that users are expected to achieve performing the learning activities.

- Resources needed.

- Financial requirements.

Step 2) Iterating cycles of implementation-findings-implications using the following table: 
Table 2. DBR design [19]

\begin{tabular}{|c|c|c|c|c|}
\hline Research Question & Variable & $\begin{array}{l}\text { Level of } \\
\text { analysis }\end{array}$ & Methods & Instruments \\
\hline $\begin{array}{l}\text { How much previous } \\
\text { knowledge do users have } \\
\text { about the stated } \\
\text { learning content? }\end{array}$ & Learning & Cognitive & $\begin{array}{l}\text { Pretest - posttest } \\
\text { comparison }\end{array}$ & $\begin{array}{l}\text { Pretest and } \\
\text { posttest }\end{array}$ \\
\hline $\begin{array}{l}\text { How is users' level of } \\
\text { engagement during } \\
\text { learning? }\end{array}$ & Learning & Cognitive & $\begin{array}{l}\text { Observation } \\
\text { (video recording, } \\
\text { or movie making } \\
\text { if inside Second } \\
\text { Life, could also be } \\
\text { used) }\end{array}$ & $\begin{array}{l}\text { Observation } \\
\text { guide }\end{array}$ \\
\hline $\begin{array}{l}\text { How do users solve the } \\
\text { problem-related } \\
\text { activities presented to } \\
\text { them? }\end{array}$ & Learning & Cognitive & Observation & $\begin{array}{l}\text { Observation } \\
\text { guide }\end{array}$ \\
\hline $\begin{array}{l}\text { How is the users' } \\
\text { motivation during } \\
\text { learning? }\end{array}$ & Learning & Cognitive & $\begin{array}{l}\text { Structured } \\
\text { interviews }\end{array}$ & $\begin{array}{l}\text { Structured } \\
\text { Interview } \\
\text { guide }\end{array}$ \\
\hline $\begin{array}{l}\text { How do the teacher } \\
\text {-student interactions } \\
\text { affect learning? }\end{array}$ & Climate & Interpersonal & $\begin{array}{l}\text { Observation } \\
\text { Unstructured } \\
\text { interviews }\end{array}$ & $\begin{array}{l}\text { Observation } \\
\text { guide Un- } \\
\text { structured } \\
\text { interview } \\
\text { guide }\end{array}$ \\
\hline $\begin{array}{l}\text { How do the student } \\
\text {-student interactions } \\
\text { affect learning? }\end{array}$ & Climate & Interpersonal & $\begin{array}{l}\text { Observation } \\
\text { Unstructured } \\
\text { interviews }\end{array}$ & $\begin{array}{l}\text { Observation } \\
\text { guide Un- } \\
\text { structured } \\
\text { interview } \\
\text { guide }\end{array}$ \\
\hline $\begin{array}{l}\text { How were the } \\
\text { collaborative learning } \\
\text { activities performed? }\end{array}$ & Climate & Group & Observation & $\begin{array}{l}\text { Observation } \\
\text { guide }\end{array}$ \\
\hline $\begin{array}{l}\text { How is the social } \\
\text { process within the } \\
\text { virtual world? }\end{array}$ & Climate & Group & Observation & $\begin{array}{l}\text { Observation } \\
\text { guide }\end{array}$ \\
\hline $\begin{array}{l}\text { What are the different } \\
\text { social roles that users } \\
\text { take during activities? }\end{array}$ & Climate & Group & Observation & $\begin{array}{l}\text { Observation } \\
\text { guide }\end{array}$ \\
\hline $\begin{array}{l}\text { How do the virtual } \\
\text { world resources } \\
\text { (physical, instructional, } \\
\text { etc.) scaffold learning? }\end{array}$ & Contextual & Resource & Observation & $\begin{array}{l}\text { Observation } \\
\text { guide }\end{array}$ \\
\hline $\begin{array}{l}\text { How has the use of the } \\
\text { virtual world diffused to } \\
\text { other teachers? }\end{array}$ & Systematic & Institutional & Structured survey & Survey \\
\hline
\end{tabular}


The DBR methodology suggests repeating the process several times, after reflecting on the reasons for going into it another time, in order to revise the design and let the theory emerge.

Step 3) Writing a final report integrating findings from all cycles.

With respect to the learning activities taking part in the environment, in order to develop valid, reliable and transferable metrics for assessing the teaching and learning effectiveness of virtual worlds, one has to analyze the quality of learning taking place using well established theoretical matrix, like Bloom's taxonomy [3] or rather its revised form [1], distinguishing between activities to range from Lower Order Thinking skills to Higher Order Thinking skills and provides a visualization of relationship between cognitive processes and knowledge as seen in Table 3.

Table 3. The taxonomy table; after Anderson et al. [1]

\begin{tabular}{|c|c|c|c|c|c|c|}
\hline \multirow{2}{*}{ Knowledge } & \multicolumn{5}{|c|}{ Cognitive process } \\
\cline { 2 - 7 } & Remember & Understand & Apply & Analyze & Evaluate & Create \\
\hline Factual & & & & & & \\
\hline Conceptual & & & & & & \\
\hline Procedural & & & & & & \\
\hline Meta-cognitive & & & & & & \\
\hline
\end{tabular}

By this categorization educational practitioners can use research outcomes to develop advice for creating assignments intended to have certain desired objectives and at the same time the activities of students during the process of virtual task implementation can be assessed in terms of their success in meeting the specified objectives.

DeFreitas and Neumann [5] suggest that the appeal, immersivity, and immediacy of virtual worlds in education requires a reconsideration of how, what, when, and where we learn and offer their Explanatory Learning Model (ELM) based upon constructivist experiential learning and using Dewey's concept of inquiry (pre-reflection, reflection, and post-reflection) to posit that learners' virtual experiences, their use of multiple media, the transactions and activities between peers, and the facilitation of learner control between them lead to "transactional learning". The use of these measurements to evaluate strategies for communicating science by using LEGO robots and a Mindstorms ${ }^{\mathrm{TM}}$ RCX controller that are collaboratively constructed and programmed by students in a virtual technology (Second Life), while the students are physically situated in different locations is deeply analyzed and well interpreted [13]. 


$$
\text { "tmcs-turcsanyi" — 2012/11/26 - 12:05 — page } 321 \text { — \#13 }
$$

\section{Conclusion}

Despite some of their disadvantages in certain cases virtual worlds can be used very well in education. In order to effectively utilize the virtual environment's opportunities and to achieve good results with this tool it is necessary in all cases that the students work in the virtual world on projects and tasks which results in active, creative, constructive and collaborative learning. With this kind of learning students could acquire deep and lasting knowledge.

Yet, careful design principles need to be adapted and well structured research processes based on sound pedagogical principles must be set up in order to verify the real values and efficiency of the resulting learning environments. We consider our present research in literature and experience with best practice examples to give us adequate munitions in empowering us to be able to set up efficient 3D learning environments for our own needs.

\section{References}

[1] L. W. Anderson, D. R. Krathwohl, P. W. Airasian, K. A. Cruicshank, R. E. Mayer, P. R. Pintrich, J. Raths and M. C. Wittrock, A taxonomy for learning, teaching and assessing: A revision of Bloom's taxonomy of educational objectives, (Abridged, ed.), Longman, New York, 2001.

[2] Association of Virtual Worlds, The Blue Book - A Consumer Guide to Virtual Worlds 7th edition [online, 2011.03.09], 2010, http://www . associationof virtualworlds . com/publication/.

[3] B. S. Bloom, (Ed.), Taxonomy of Educational Objectives, the classification of educational goals, . Handbook 1: Cognitive Domain, McKay, New York, 1956.

[4] A. L. Brown, Design Experiments: Theoretical and methodological challenges in creating complex interventions in classroom settings, Journal of the Learning Sciences 2, no. 2, 1992, 141-178.

[5] S. Defreitas and T. Neumann, The use of "exploratory learning" for supporting immersive learning in virtual environments, Computers \& Education 52, 2009, 343-352.

[6] M. Esteves, B. Fonseca, L. Morgado and P. Martins, Using Second Life for Problem Based Learning in Computer Science Programming, Journal of Virtual Worlds Research: Pedagogy, Education and Innovation in 3-D Virtual Worlds, 2009, April, 2009, ISSN 1941-8477.

[7] J. Geigel, Teaching Animation in Virtual Space: The Use of Second Life as An Extended Approach for Teaching Computer Graphics Courses On-Line [online, 2011.01.02], The Journal of Virtual Worlds and Education 1, no. 1 (2010), 37-62, http://jvwe.org/publications/jvwe-volume-one-number-one.pdf. 


$$
\text { "tmcs-turcsanyi" — 2012/11/26 — 12:05 — page 322 — \#14 }
$$

[8] R. Hemls, E. Giovacchini and R. Teigland, A Design Research Approach to Developing User Innovation Workshops in Second Life [online, 2011.03.09], Journal of Virtual Worlds Research: The Researcher's Toolbox 3, no. 1, 2010, November 2010, ISSN: 1941-8477, http://www.jvwresearch.org/page/volume_3_number_1_the_researchers_toolbox.

[9] Ch. Inman, V. H. Wright and J. A. Hartman, Use Second Life in K-12 and Higher Education: A review of Research, Journal of Interactive Online Learning 9, no. 1, 2010, Spring 2010. ISSN 1541-4914.

[10] A. Levine, Two Minute Survey on What's Happening in Virtual Worlds [online, 2011.01.01], New Media Consortium, 2010, http://www.nmc .org/2minute-survey/virtual-worlds.

[11] K. Y. T. Lim, The six learnings of Second Life: A framework for designing curricular interventions in-world, Journal of Virtual Worlds Research: Pedagogy, Education and Innovation in 3-D Virtual Worlds, 2009, April, 2009, ISSN 1941-8477.

[12] H. Marešová, Vzdělávaní v Second Life (Education in Second Life) [online, 2010.12.12], Nové technológie ve vzdělávání, 2010, Olomouc, 2010, http://www.kteiv.upol.cz/ntvv/konference/maresova_h.pdf.

[13] S. Martin, M. Vallance, P. Schaik and C. Wiz, Learning spaces, tasks and metrics for effective communication in Second Life within the context of programming LEGO NXT Mindstorms ${ }^{\mathrm{TM}}$ robots: towards a framework for design and implementation [online, 2011.03.09], Journal of Virtual Worlds Research: The Researcher's Toolbox 3, no. 1, 2010, November 2010, ISSN: 1941-8477, http://www.jvwresearch.org/page/volume_3_number_1_the_researchers_toolbox.

[14] P. Michels, Universities Use Second Life to Teach Complex Concepts [online, 2010.12.12], Govtech.com., 2008, http://www.govtech.com/education/Universities-Use-Second-Life-to-Teach.html.

[15] P. Penfold, Learning Through the World of Second Life - A Hospitality and Tourism Experience [online, 2011.01.01], Journal of Teaching in Travel \& Tourism. 8, no. 2 \& 3, 2008, 139-160,

http: //www. informaworld. com/smpp/section? content=a909204447\&fullt ext $=713240928$.

[16] A. Pereira, P. Martins, L. Morgado and B. Fonseca, A virtual environment study in entrepreneurship education of young children, Journal of Virtual Worlds Research: Pedagogy, Education and Innovation in 3-D Virtual Worlds, 2009, April, 2009, ISSN 1941-8477.

[17] P. Roush, M. Nie and M. Wheeler, Between Snapshots and Avatars: Using Visual Methodologies for Fieldwork in Second Life, Journal of Virtual Worlds Research: Pedagogy, Education and Innovation in 3-D Virtual Worlds, 2009, April, 2009, ISSN 1941-8477.

[18] M. Sahin, Language Teaching in Second Life [online, 2010.6.25], 2010, http://sl4calico.pbworks. com/f/Language+Teaching+in+SL.ppt.

[19] A. Santos, Using Design-Based Research for Virtual Worlds Research Projects [online, 2011.03.09], Journal of Virtual Worlds Research: The Researcher's Toolbox 3, 


$$
\text { "tmcs-turcsanyi" — 2012/11/26 — 12:05 — page } 323 \text { — \#15 }
$$

no. 1, 2010, November 2010, ISSN: 1941-8477,

http://www.jvwresearch.org/page/volume_3q_number_1q_the_researchers_toolbox.

[20] A. Schmeil and M. J. Eppler, Knowledge Sharing and Collaborative Learning in Second Life: A Classification of Virtual 3D Group Interaction Scripts, Journal of Universal Computer Science 14, no. 3 (2008).

[21] M. Smith and Z. L. Berge, Social Learning Theory in Second Life [online, 2011.01.01], MERLOT Journal of Online Learning and Teaching 5, no. 2, 2009, June 2009, http://jolt.merlot.org/vol5no2/berge_0609.htm.

[22] V. Vaishnavi and W. Keuchler, Design Research in Information Systems [online 2011.03.09], Association for Information Systems, 2004, http: //home . aisnet .org/displaycommon. $c f m$ ?an=1\&subarticlenbr=279.

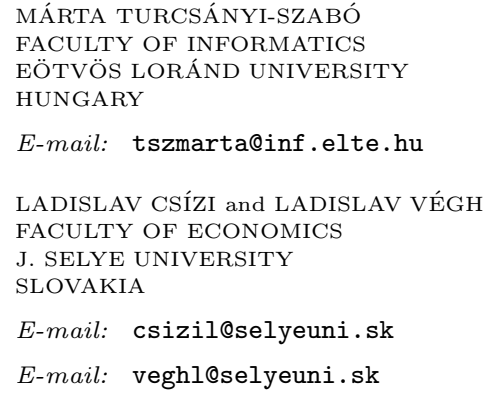

(Received September, 2011) 